\title{
Harnessing Natural Colorants for Sustainable Textile Dyeing an Eco-Friendly Approach Using Sweet Cane (Saccharum Bengalense Retz.) Inflorescence
}

\author{
Ali Raza ${ }^{1}$, Naeem Iqbal $^{1 *}$, Saqib Mahmood ${ }^{1}$, Shagufta Parveen ${ }^{1}$, Muhammad Azeem ${ }^{1}$, \\ Muhammad Nawaz ${ }^{1}$, M Tariq Javed ${ }^{1}$, Ali Noman'1 \\ ${ }^{I}$ Department of Botany Govt. College University 38000, Faisalabad Pakistan
}

\begin{abstract}
The excessive industrial use of dye producing plants has threatened the existence of these species and biodiversity. Exploration of abundantly available natural dye sources not only provide industrial benefits but also share the load of dye yielding plants. In the present study we used the inflorescence of munj sweet cane (Saccharum bengalense Retz.) to extract natural colorant for textile industry. This easily available plant is cheap source of natural colorants and good alternative of synthetic dyes. The munj sweet cane inflorescence extract and fabric was treated with microwave radiations. The dyeing aspects like temperature, time, fabrics to extract ratio, salt type and salt concentrations were optimized. Pre-and post mordanting was carried out and optimized using copper, iron, moringa and turmeric. All the samples were analyzed by spectra flash D65 10 Deg to determine the color strength (\%) value. Results proved inflorescence extract of munj sweet cane (RS, two minutes) using aqueous media as a good source of natural dye. Three grams of sodium chloride as exhaustion agent was observed to be the best while $70^{\circ} \mathrm{C}$ temperatures gave best colour strength. Among chemical mordants, iron proved to be good one for producing varying shades and better colour strength. Bio mordanting with turmeric was proved to be more beneficial for getting best color strength and new shades.
\end{abstract}

Keywords: Irradiation, Natural dye, Munj sweetcane, Color fastness, Mordanting, Spectraflash

\footnotetext{
** Author for correspondence: naeemgc@yahoo.com
} 


\section{INTRODUCTION}

The large-scaled use of synthetic dyes in textile processing has aggravated the environmental as well as human health related problems. Therefore, a dire need exists regarding the exploration of natural dyes for textile sector. Exploration of ecologically and economically efficient natural colorant sources is the prerequisite for sustainable textile dyeing. Owing to less identified sources of natural colorants, fewer shades and weak color strength, the synthetic chemicals have substituted the natural dye in past decades ${ }^{1}$ Hence, exploitation of more natural colorant sources and improvement in color fastness characteristics should be the priority areas for the scientist working to promote the use of natural products. Plants, the prominent and abundant source of colorant have been utilized for dyeing textile products since ancient times ${ }^{2}$. Although it is a known fact that human beings know about the existence of hundreds of thousands plant species but only a negligible proportion of this natural wealth have been explored for textile dying ${ }^{3}$. Mostly, the floral parts of the plants are being used for natural coloring compounds in textile industries ${ }^{4}$. The poor extraction of colorant from plants is one of the main hindrances of their use in modern textile because very little amount of natural coloring compounds can be extracted in water. Hence, extraction of coloring compounds is done by the rupturing of plant cell wall ${ }^{5}$. For the improvement of dye extraction and color fastness characterization, scientists have used different technologies such as suitable extraction media ${ }^{4,6}$ and radiation treatments ${ }^{7,8}$.

Radiations have a great influence on the biological and medical sciences as well as the chemical industry ${ }^{9,10}$. In textile dyeing, the microwave and UV radiations are generally used for enhancing the dyeing ability of colorants and obtaining extract from the crude materials ${ }^{11}$. It has been established that treatment of dyeing fabric and the crude plant material with UV radiations improves the quality of dye and color fastness ${ }^{11,12}$. Radiation technology is also being used for the improvement of color extraction and

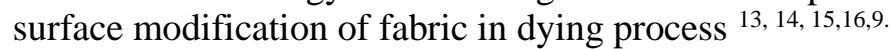

The munj sweet cane (Saccharum bengalense Retz.) a fast-growing perennial of Poaceae is found in most parts of the world ${ }^{17}$. It has been used as biosorbent to absorb the Cobalt, $\mathrm{Ni}{ }^{18}$ and $\mathrm{Pb}$ compounds from contaminated area ${ }^{9}$. Photochemical and psycomorphological studies of this plant show that it contains many medicinally important products ${ }^{19}$. The stem extract contains many compounds such as glycosides, alkaloids, steroids and tannins, hemicelluloses, pectin and lignins ${ }^{18}$. Mature inflorescence is golden to dark brown in color. Munj sweet cane reproduces by both seeds and vegetative methods. Axiliry buds on the stem are also helpful to disperse the plant in new and existing areas. Hence, it spreads rapidly excluding many plant species, thus acting as invader to the natural and agricultural areas ${ }^{20}$. In Pakistan, it is abundantly found along the roadsides, rivers, canals and water channels. It becomes dominant by producing large amount of bio mass and dormant seeds ${ }^{21,22}$. Physical eradication by fire and cutting the above ground biomass is the basic method to control this weed ${ }^{23}$. The surplus plant material is treated as waste so the use of this plant as a source of natural colorant may not disturb biodiversity and natural flora.

Keeping in view the abundant availability of munj sweet cane, the study has been carried out to explore the colorant behavior of this plant under the influence of microwave radiations for textile dyeing, so that the textile sector may have an easily available and cheap source of natural dyes. 


\section{MATERIAL AND METHOD}

\section{Sample Preparation}

Mature and healthy munj sweet cane inflorescence was collected from the noncultivated areas of the Faisalabad, Pakistan. The collected material was oven dried for 48 hours at $75{ }^{\circ} \mathrm{C}$ and grinded into powder ${ }^{24}$. The Viscose fabric used for dyeing was treated with $\mathrm{NaOH}$ solution ( $3 \%$ ) for 10 minutes, boiled with baby soap $(8.0 \mathrm{~g})$ for about 30 minutes and dried.

\section{Extraction and Irradiation Process}

The colorant extraction from munj sweet cane inflorescence powder was done by boiling and microwave assisted method. In boiling method, the extract was obtained by heating powder $(1.0 \mathrm{~g})$ in $30 \mathrm{ml}$ of liquid medium for 45 minutes at $90{ }^{\circ} \mathrm{C}$. In microwave assisted method, the extract was obtained by the same method described above in addition to exposure of extract to microwaves for 1 to 10 minutes using microwave oven (DW-MD4) for each sample, separately ${ }^{25}$. The dyeing process was carried out using non-radiated powder/non-radiated viscose (NRP/NRV) and radiated powder/radiated viscose (RP/RV). The extracts obtained were used for further experimentation.

\section{Optimization of Dyeing Parameters}

The dyeing conditions such as time interval, temperature, material liquor (M: L) ratio, salt type and salt concentrations were optimized using RS/RV (radiated extract solution and radiated viscose). To optimize time interval, the radiated fabric was dyed for different time periods $\left(15,25,35,45,55\right.$ and 65 minutes) at $70^{\circ} \mathrm{C}$ using $3.0 \mathrm{~g} \mathrm{NaCl}$ salt. Dyeing temperature was optimized by dyeing the fabric separately at temperature 30 , $40,50,60,70$ and $80{ }^{\circ} \mathrm{C}$ for 55 minutes using $3.0 \mathrm{~g} \mathrm{NaCl}$ salt. Two types of salts, $\mathrm{NaCl}$ and $\mathrm{Na}_{2} \mathrm{CO}_{3}$ at the concentrations of $1,2,3,4$ and $5 \mathrm{~g} / \mathrm{L}$ for each sample, were used to optimize the best salt concentration (Khan et al. 2014). The color strength (\%) and lab values were determined at $C^{*} I^{*} E^{*}$ lab of Noor Fatima Fabrics (Pvt.) Ltd, Faisalabad.

\section{Optimization of Mordanting Conditions}

The mordantig was carried out using chemicals like copper sulphate, iron sulphate and biomordants, such as turmeric (Curcuma longa L.) and moringa (Moringa oleifea Lam.) as pre- and post-mordanting agents. Viscose fabric was dyed with each of these mordants separately at different concentration 1, 2, 3, 4 and $5 \mathrm{~g} / 100 \mathrm{~mL}$. The dyeing process was carried out at $70{ }^{\circ} \mathrm{C}$ for 55 minutes using $3.0 \mathrm{~g} \mathrm{NaCl}$ salt as exhausting agent. The dyed fabrics were washed and dried at room temperature.

\section{Evaluation of Quality Characteristics Of Dyes And Fabrics}

In order to observe the effect of microwave radiation on colour fastness properties of viscose fabric dyed with munj sweetcane inflorescence extract, standard ISO methods were used. For the purpose, different methods such as, ISO $105 \mathrm{CO} 3$ for washing using rota wash and ISO BO2 for light using fado meter was employed. All the samples were subjected to CIE Lab system using spectra flash spectrophotometer SF 650 with an illuminant of D65 10 Deg observer for evaluation of colour strength ${ }^{25}$. 


\section{RESULTS AND DISCUSSION}

The results from dye extraction experiments indicated that natural colorants from munj sweet cane inflorescence could be best obtained using aqueous than those of alkaline media, after two minutes microwave treatment to the dye solution (Figure 1). This showed that water imbibed by the plant material relaxed the cell wall that helped to release the dye compound by boiling ${ }^{26}$. The results showed that microwave radiations treatment must also have contributed towards loosening of cell wall and released the coloring compounds ${ }^{27}$. The good color strength of microwave treated aqueous extract of munj sweet cane inflorescence was obtained on microwave irradiated viscose (RV) fabrics (Figure 1). The relatively high compatibility of irradiated compared to nonirradiated viscose (NRV) fabric towards microwave treated (02 minutes) inflorescence extract could be explained by the fact that radiations treatment caused surface modifications of the fabric that facilitated dye sorption ${ }^{16}$. More than two minutes irradiation time might have degraded the colorant, which resulted in low color depth at higher microwave doses ${ }^{28,29}$. The optimum extraction conditions were two minutes microwave treatment to plant extract in aqueous media.

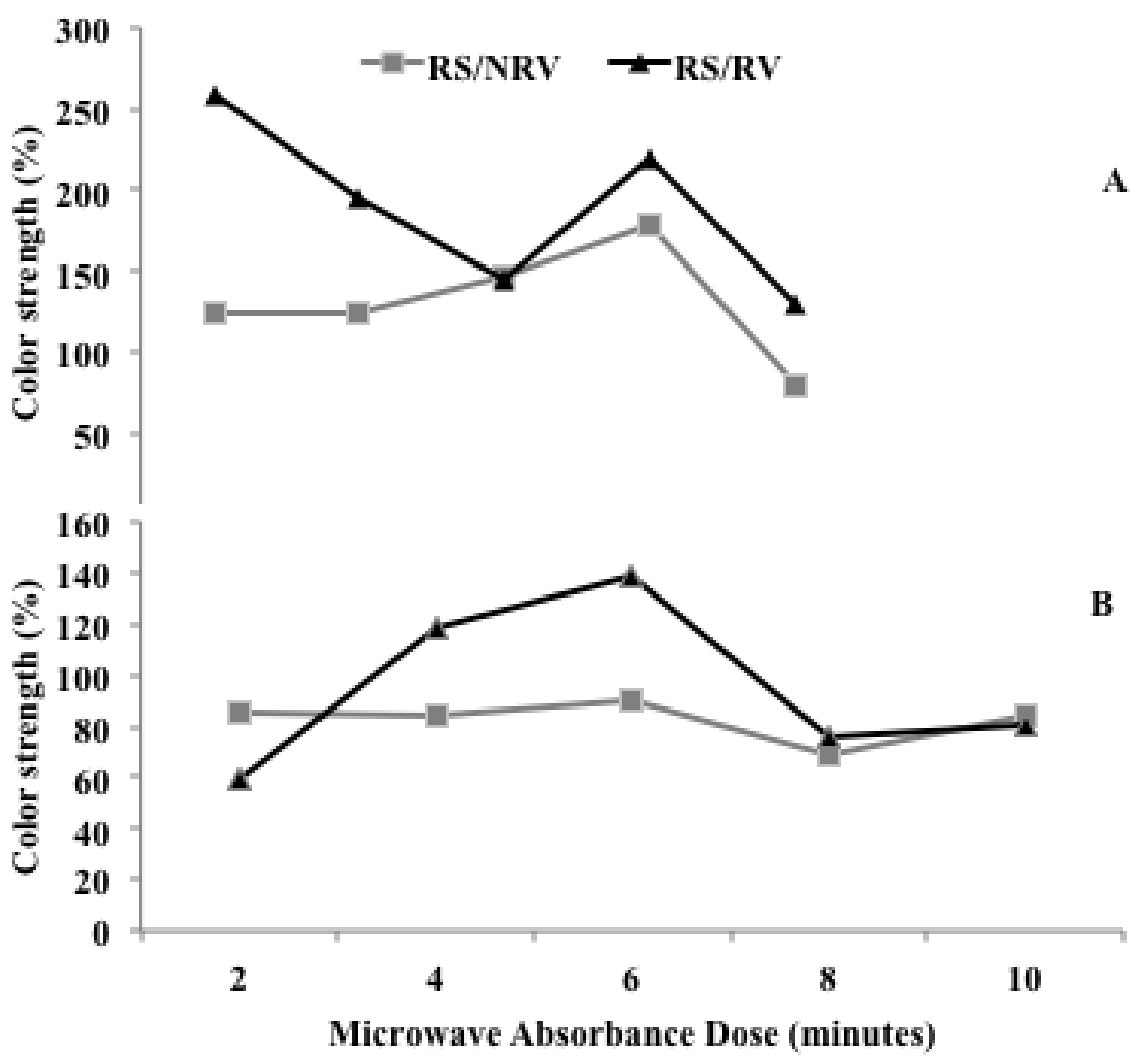

Figure 1: Effect of microwave treatments on color strength of viscose fabric dyed with aqueous (a) and alkaline (b) extract of munj sweetcane

The results of the studies regarding the effects of dyeing interval showed that the color strength was enhanced by increasing the dyeing time (Figure 2). More the dyeing time meant more the color strength. The molecules of dye rushed onto the fabric continuously as the dyeing time was increased until it reached its maximum for 55 minutes. At optimal time of 55 minutes both rate of dyeing and stripping came into equilibrium and colorant got maximum chance to sorb onto modified fabric. Microwave treatment to both fabric and inflorescence extract for eight minutes reduced the dyeing time and enhanced color strength. 


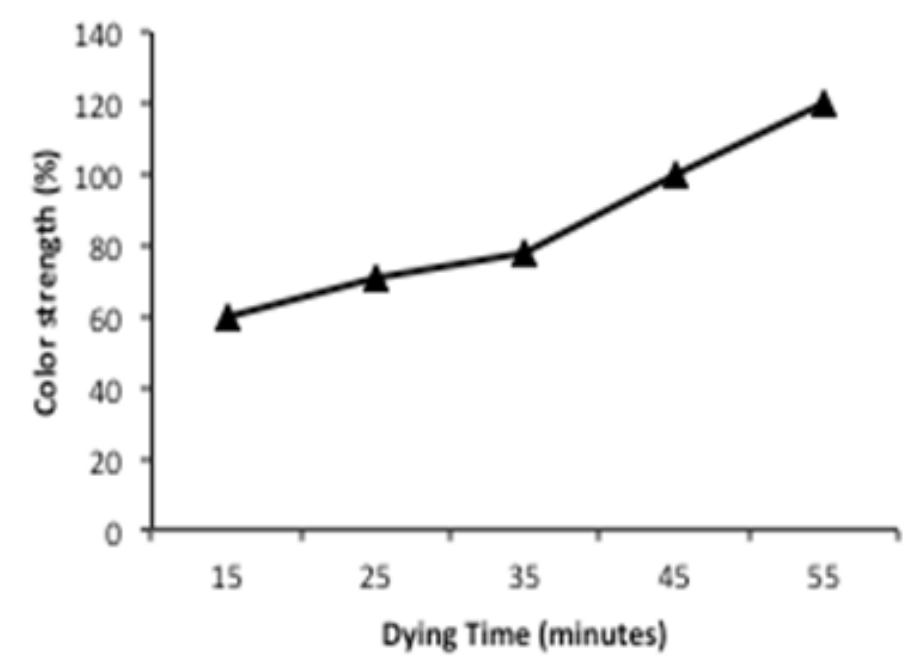

Figure 2: Effect of dying time on color strength of viscose fabric dyed with munj sweet cane inflorescence extract.

The results showed (Figure 3) that addition of sodium chloride (table salt) in the dyeing medium produced maximum color depth compared to sodium sulfate (Glauber salt). It also has been reported that salt addition to dye bath helped in maximum exhaustion ${ }^{30}$. Addition of $3 \%$ table salt in the dyeing medium pulled the colorant towards fabric within short range of attractive forces resulting high color strength values. Lower than $3 \%$ of salt gave reduced exhaustion and addition of high amount (> 3\%) of salt resulted over exhaustion. Higher salt concentration decreased the intraction between dye molecules and fabric causeing degradation of the dye molecule ${ }^{31}$. Microwave treatments reduced amount of salt used.

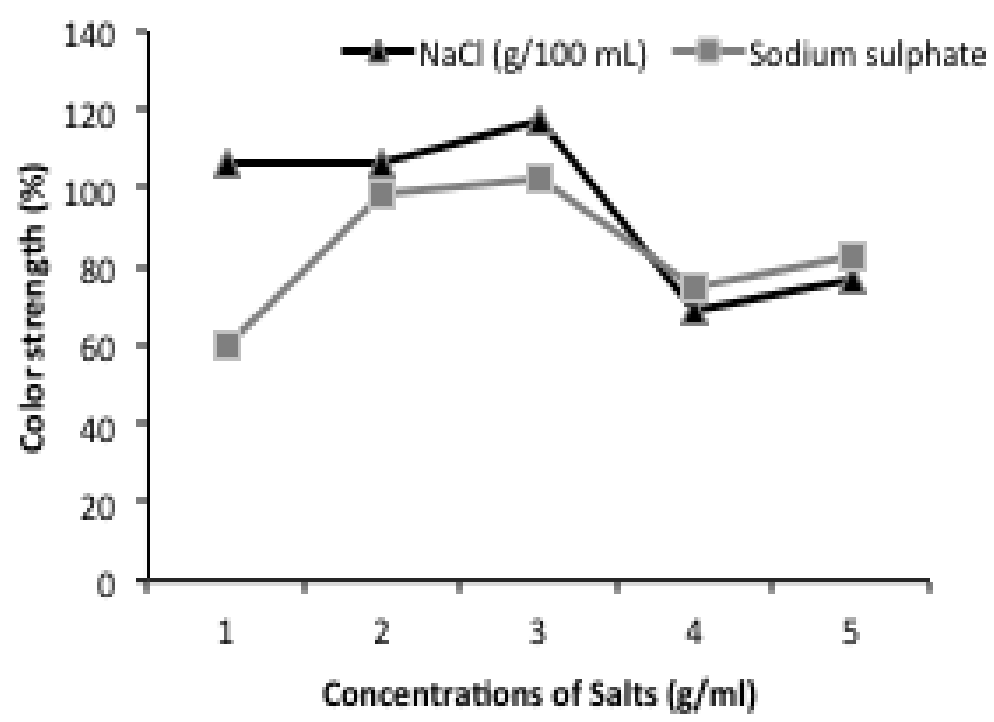

Figure 3. Effect of salt addition in dyeing bath on color strength of viscose fabric dyed with munj sweetcane inflorescence extract.

The results revealed that $70{ }^{0} \mathrm{C}$ was the optimal temperature for dyeing of irradiated viscose using irradiated munj sweetcane inflorescence extract (Figure 4). At $70{ }^{\circ} \mathrm{C}$, high level dyeing was achieved due to high rate of dyeing. Thus $70{ }^{\circ} \mathrm{C}$ was revealed for natural dyeing; at this temperature, the colorant kinetic energy become optimum to 
make firm bonding with viscose ${ }^{31}$. Further increase in dyeing temperature $\left(>70{ }^{0} \mathrm{C}\right)$ caused decline in colour strength.

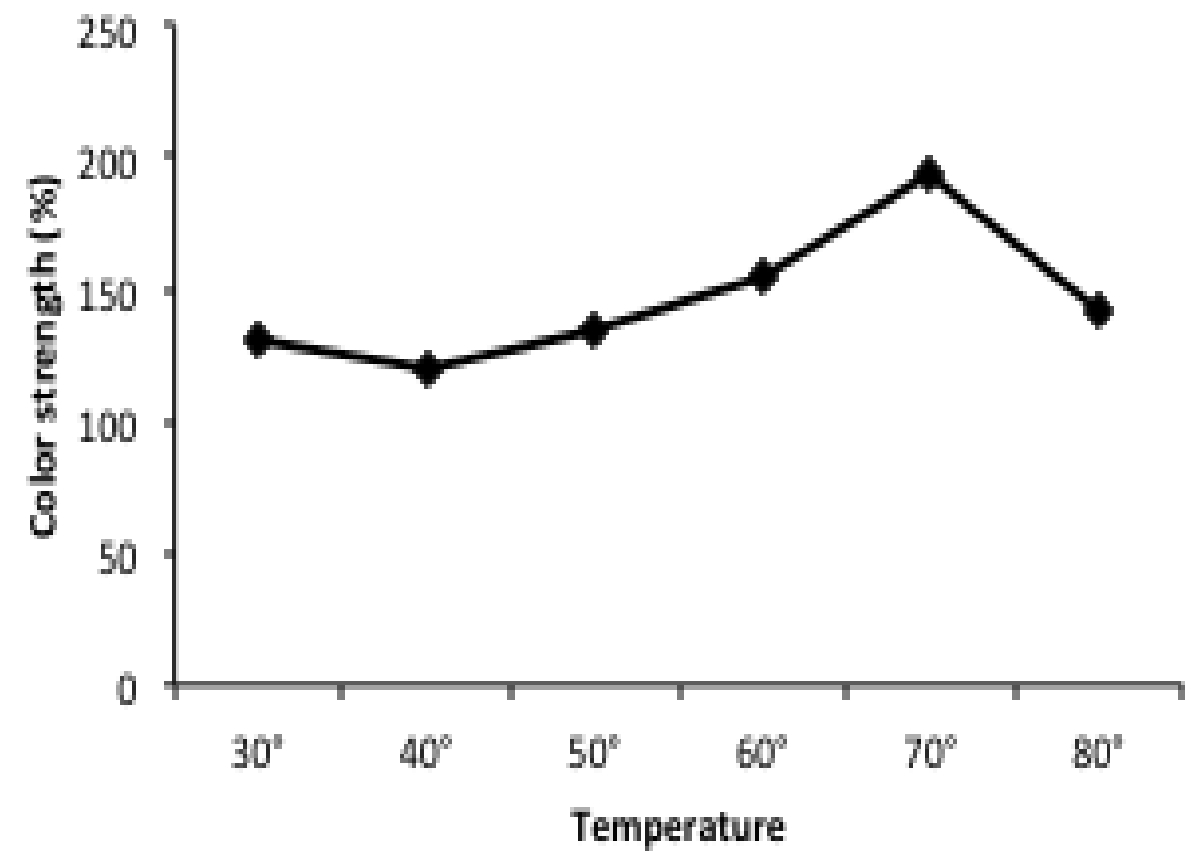

Figure 4: Effect of temperature of dye bath on color strength of viscose fabric dyed with munj sweetcane inflorescence extract.

The mordanting experiments results (Figure 5a, b, c, d, Table 1,2) revealed that though all the mordants improved fabric shades and color strength; post mordanting with bio mordants gave relatively good color strength (Figure 5d). Among biomordants, $3 \%$ of turmeric produced high color depth. The bonding between dye and fabric as well as conjugation system of bio-mordant helped to impart good impact of color on surface modified fabrics. Among chemical mordants, iron @ 3\% as pre-and 9\% as post mordant gave great color strength. Iron sulphate formed the complex with dye molecule at one end and with fabric at other end that helped to stay the dye molecules on the fabric surface ${ }^{32}$. The relatively lower reaction power of iron than copper made the bonding with viscose stronger with dye and metal. Addition of higher amount of mordant might caused aggregate of complex to gather on to fabric resulting into weak bonding. Chemical mordants showed least color strength because the mordants formed insoluble complex with dye molecules that decreased the adsorption on fabric ${ }^{33,}{ }^{34}$. Microwave treatment of turmeric showed more interaction as compared to tannins of moringa (Moringa olefera Lam.). This might be due to the interaction of turmeric onto fabric via H-bonding making stable complex, resulting into good color depth. Samples of viscose fabric dyed with munj sweet cane inflorescence extract under optimum conditions is given in Figure 6. 

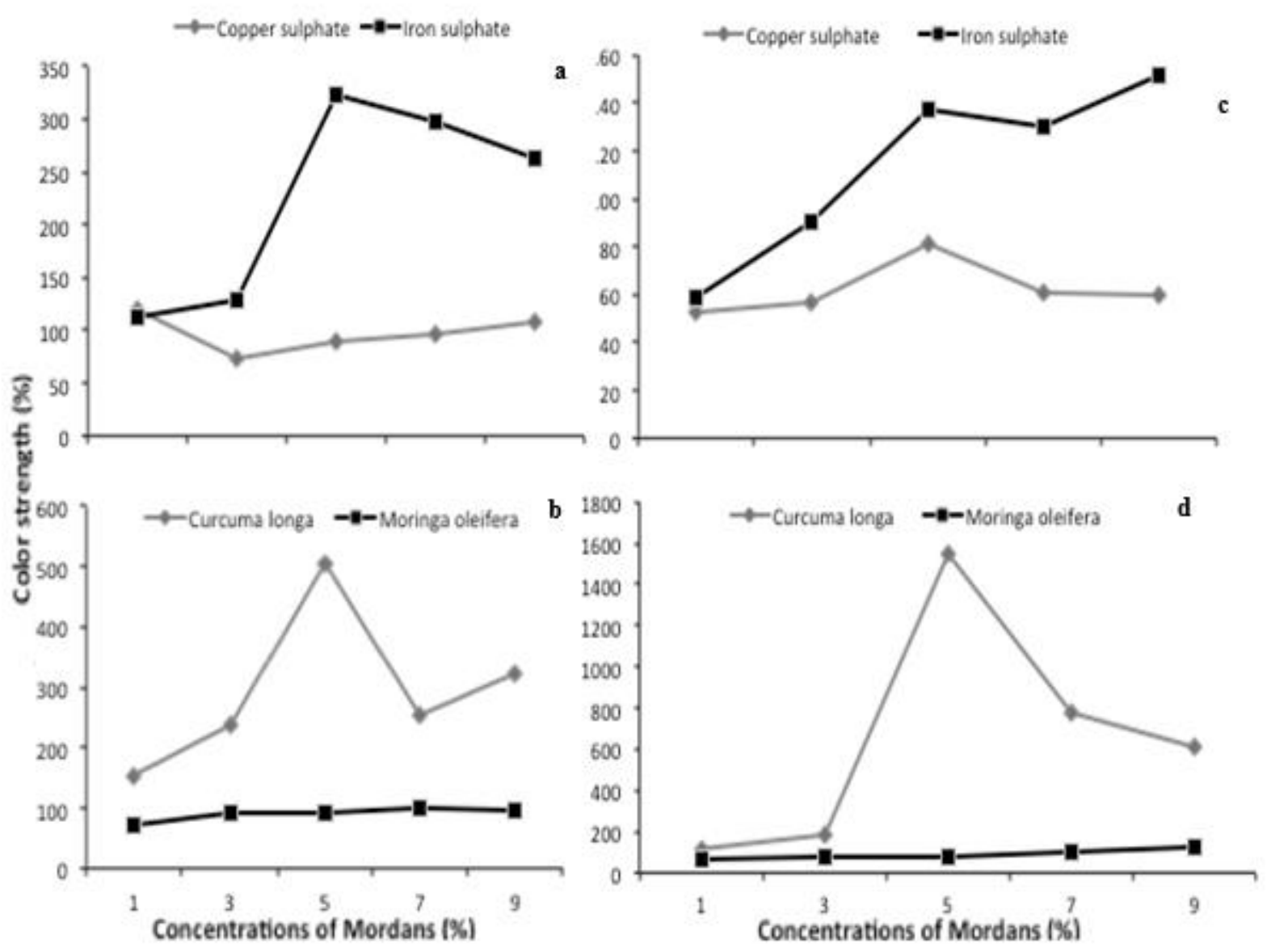

Figure 5: Effect of mordants on color strength of viscose fabric dyed with munj sweetcane inflorescence extract. Pre mordanting with chemical mordants (5a), post mordanting with chemical mordants $(5 \mathrm{~b})$, pre mordanting with bio mordants $(5 \mathrm{c})$, post mordanting with bio mordants $(5 \mathrm{~d})$

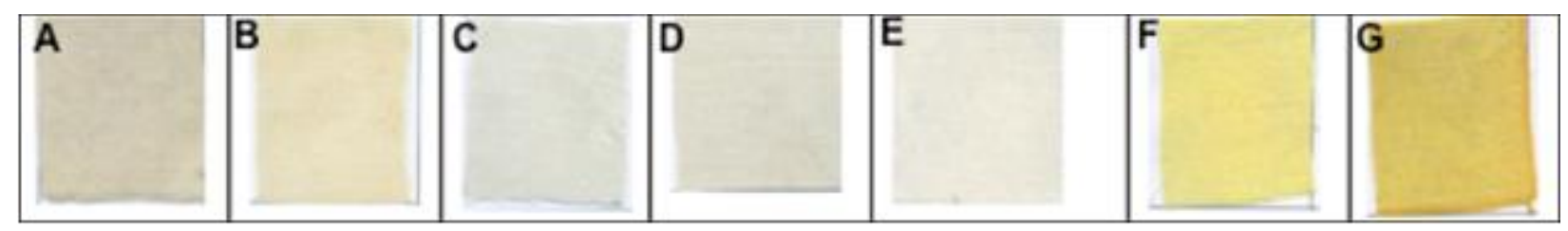

Figure 6: Sample of viscose fabric dyed with munj sweetcane inflorescence extract under optimum conditions. (A) Aqoues medium (B) Alkaline medium (C) Dyeing Time
(D) Dyeing temp (E)Salt concentration
(F) Pre Mordantig
(G) Post mordanting 
Table 1: Effect of microwave radiation on colourfastness properties of pre mordanted viscose fabric dyed with munj sweetcane inflorescence extract at optimal conditions.

\begin{tabular}{|c|c|c|c|}
\hline Mordanting agents & $\begin{array}{l}\text { Mordant } \\
\text { concentrations }\end{array}$ & $\begin{array}{l}\text { Wash } \\
\text { fastness }\end{array}$ & $\begin{array}{l}\text { Light } \\
\text { fastness }\end{array}$ \\
\hline \multirow[t]{5}{*}{ Copper sulphate } & $1 \mathrm{~g}$ & 3 & 3 \\
\hline & $2 g$ & 3 & 4 \\
\hline & $3 g$ & 2 & 4 \\
\hline & $4 g$ & 3 & 3 \\
\hline & $5 g$ & 3 & 3 \\
\hline \multirow[t]{5}{*}{ Iron sulphate } & $1 g$ & 5 & 5 \\
\hline & $2 \mathrm{~g}$ & 5 & 4 \\
\hline & $3 g$ & 5 & 4 \\
\hline & $4 g$ & 3 & 3 \\
\hline & $5 g$ & 3 & 4 \\
\hline \multirow[t]{5}{*}{ Turmeric } & $1 \mathrm{~g}$ & 5 & 5 \\
\hline & $2 \mathrm{~g}$ & 2 & 4 \\
\hline & $3 g$ & 3 & 4 \\
\hline & $4 g$ & 3 & 5 \\
\hline & $5 g$ & 3 & 3 \\
\hline \multirow[t]{5}{*}{ Moringa } & $1 \mathrm{~g}$ & 3 & 4 \\
\hline & $2 g$ & 4 & 3 \\
\hline & $3 g$ & 4 & 4 \\
\hline & $4 g$ & 5 & 4 \\
\hline & $5 g$ & 3 & 3 \\
\hline
\end{tabular}

Table 2: Effect of microwave radiation on colourfastness properties of post mordanted viscose fabric dyed with munj sweetcane inflorescence extract at optimal conditions.

\begin{tabular}{|c|c|c|c|}
\hline Mordanting agents & $\begin{array}{l}\text { Mordant } \\
\text { concentrations }\end{array}$ & $\begin{array}{l}\text { Wash } \\
\text { fastness }\end{array}$ & Light fastness \\
\hline \multirow[t]{5}{*}{ Copper sulphate } & $1 \mathrm{~g}$ & 3 & 4 \\
\hline & $2 g$ & 2 & 4 \\
\hline & $3 g$ & 2 & 3 \\
\hline & $4 g$ & 4 & 4 \\
\hline & $5 g$ & 4 & 3 \\
\hline \multirow[t]{5}{*}{ Iron sulphate } & $1 g$ & 4 & 3 \\
\hline & $2 g$ & 2 & 3 \\
\hline & $3 g$ & 5 & $3-4$ \\
\hline & $4 g$ & 5 & $2-3$ \\
\hline & $5 g$ & 2 & 3 \\
\hline \multirow[t]{5}{*}{ Turmeric } & $1 \mathrm{~g}$ & 2 & $2-3$ \\
\hline & $2 g$ & $1-2$ & 4 \\
\hline & $3 g$ & $2-3$ & 3 \\
\hline & $4 g$ & $1-2$ & 3 \\
\hline & $5 g$ & 4 & 4 \\
\hline \multirow[t]{5}{*}{ Moringa } & $1 g$ & 3 & 5 \\
\hline & $2 g$ & 4 & 4 \\
\hline & $3 g$ & $4-5$ & 3 \\
\hline & $4 g$ & 3 & 4 \\
\hline & $5 g$ & 4 & 4 \\
\hline
\end{tabular}


The results of the present study clearly revealed that the munj sweet cane (Saccharum bengalense Retz.) inflorescence could be a potential source of natural colorants for textile dyeing. Moreover, iron as chemical and turmeric as biomordant may be recommended for dyeing of irradiated viscous using un-irradiated extract of munj sweet canes inflorescence.

\section{REFERENCES}

1. O'Bannon G \& Oriental R. The Collector's Guide to Selecting, Identifying, and Enjoying New and Vintage Oriental Rugs. Quintet Publishing, Ltd., Courage Books, Philadelphia, Pennsylvania.1995.

2. Devi M, Ariharan VN \& Prasad, N. Annato, eco-friendly and potential source for natural dye. International Research Journal of Pharmacy. 2003; 4: 106-108.

3. Hull A, Jose Lw \& Nicolas B. The Complete Guide. History, Pattern, Technique, Identification. Thames and Hudson, London, U.K. 1993

4. Ali S, Hussain T \& Nawaz R . Optimization of alkaline extraction of natural dye from Henna leaves and its dyeing on cotton by exhaust method. J Clean Prod. 2009; 17: 61-66.

5. Sivakumar V, Vijaeeswarri J \& Anna JL. Effective natural dye extraction from different plant materials using ultrasound. Industrial Crop and Products. 2011; 33: 116-122.

6. Sinha K, Aikat K, Das P \& Datta S. Dyeing of modified cotton fiber with natural

Terminalia arjuna dye: Optimization of dyeing parameters using response surface methodology. Environmental Progress \& Sustainable Energy. 2016; 35: 719-728.

7. Cuoco, G, Mathe C, Archier P, Chemat F \& Vieillescazes C. A multivariate study of the performance of an ultrasound-assisted madder dyes extraction and characterization by liquid chromatography-photodiode array detection. Ultrasonics Sonochemistry. 2009; 16: 75-82.

8. Ajmal M, Adeel S, Azeem M, Zuber M, Akhtar N \& Iqbal N. Modulation of pomegranate peel colourant characteristics for textile dyeing using high energy radiations. Industrial Crops and Products. 2014; 58: 188-193.

9. Batool F, Adeel S, Azeem M, Khan AA, Bhatti IA, Ghaffar A, \& Iqbal N. Gamma radiations induced improvement in dyeing properties and colorfastness of cotton fabrics dyed with chicken gizzard leaves extracts. Radiation Physics and Chemistry. 2013; 89: 33-37.

10. Chaudhari CV, Guin JP, Dubey KA, Bhardwaj YK, and Varshney L. Radiation induced grafting of glycidyl methacrylate on teflon scrap for synthesis of dual type adsorbent Process parameter standardisation. Environmental Progress \& Sustainable Energy. 2006; 35: 1367-1373. 11. Bhatti IA, Adeel S, Siddique S \& Abbas M. Effect of UV radiation on the dyeing of cotton fabric with reactive blue 13. J Saudi Chem socie Socie. 2014; 18: 606-609.

12. Bhatti IA, Adeel S, Parveen S \& Zuber M. Dyeing of UV irradiated cotton and polyester fabrics with multifunctional reactive and disperse dyes. J Saudi Chem Socie. 2016; 20: 178-184. 13. Sinha K, Saha PD \& Datta S. Response surface optimization and artificial neural network modeling of microwave assisted natural dye extraction from pomegranate rind. Industrial Crops and Production. 2012; 37: 408-414.

14. Adeel S, Bhatti IA, Kausar A, \& Osman E. Influence of UV radiations on the extraction and dyeing of cotton fabric with Curcuma longa L. Indi J Fibre \& Text Resea. 2012; 37, 87.

15. Bhatti IA, Adeel S, Irshad M \& Abbas M. Effect of mercerization and gamma irradiation on the dyeing behaviour of cotton using stilbene based direct dye. Radiotion Physics and Chemistry. 2012; 81: 823-826.

16. Sinha K, Chowdhury S, Saha PD \& Datta S. Modeling of microwave-assisted extraction of natural dye from seeds of Bixa orellana (Annatto) using response surface methodology (RSM) and artificial neural network. Industrial Crops and Products. 2013; 4: 165-171.

17. Din MI, Hussain Z, Mirza ML, Athar MM, Madni A, \& Ahmad S. Biosorption of toxic congo red dye from aqueous solution by eco-friendly biosorbent Saccharum bengalense kinetics and thermodynamics. Desalination and Water Treatment. 2013; 51: 5638-5648.

18. Din MI \& Mirza LM. Biosorption Potentials of a Novel Green Biosorbent Saccharum bengalense Containing Cellulose as Carbohydrate Polymer for Removal of Ni (II) Ions From Aqueous Solutions. Interna J Bio Macromol. 2013; 54: 99-108. 
19. Kumar CAS, Varadharajan R, Muthumani P, Meera R, Devi P \& Kameswari B. Psychopharmacological studies on the stem of Saccharum spontaneum. Interna J Pharm Tech Reserche. 2010; 2: 319-321.

20. D'Antonio CM, \& Vitousek PM. Biological invasions by exotic grasses, the grass/fire cycle, and global change. Annual Review of Ecology, Evolution and Systematics. 1992; 23: 6387.

21. Donohue K, de Rubio C, Burghardt L, Kovach, K, Willis CG. Germination, postgermination adaptation, and species ecological ranges. Annual Review of Ecology, Evolution and Systematics. 2010; 41: 293-319.

22. Lambert, AM, Dudley TL, \& Saltonstall K. Ecology and impacts of the large-statured invasive grasses Arundo donax and Phragmites australis in North America. Invasive Plant Science and Management. 2010; 3: 489-494.

23. Bonnett, G, Kushner J, \& Saltonstall K. The reproductive biology of Saccharum spontaneum L., implications for management of this invasive weed in Panama. Neo Biota. 2014; 20: 61-79.

24. Khan AA, Iqbal N, Adeel S, Azeem M, Batool F, \& Bhatti IA. Extraction of natural dye from red calico leaves, gamma ray assisted improvements in colour strength and fastness properties. Dyes and Pigments. 2014; 103: 50-54.

25. Kumaresan, M, Palanisamy PN, \& Kumar PE. Dyeing of silk fabric with eco-friendly natural dyes using single mordants Comparison of fastness properties and colour strength. International Journal of Research in Pharmaceutical and Biomedical Sciences. 2012; 3: 16141620 .

26. Saxena S \& Raja ASM. Natural Dyes, Sources, Chemistry, Application and Sustainability Issue In Roadmap to Sustainable Textiles and Clothing. Springer Singapore. 2014; 37-80.

27. Bagherian H, Ashtiani ZF, Fouladitajar A \& Mohtashamy M. Comparisons between conventional, microwave-and ultrasound-assisted methods for extraction of pectin from grapefruit. Chemical Engineering and Processing. 2011; 50: 1237-1243.

28. Muneer M, Adeel S, Ayub S, Zuber M, Ur-rehman F, Kanjal ML, Iqbal M \& Kamran M. Dyeing behaviour of microwave assisted surface modified polyester fabric using disperse orange: improvement in colour strength and fastness properties. Oxidation Communication. 2016; 39: 1430-1439.

29. Almahy HA, Ali MA, \& Band AA. Extraction of Carotenoids as Natural dyes from the Daucus carota Linn (carrot) using Ultrasound in Kingdom of Saudi Arabia. Reserch J Chemi Scie. 2013; 3: 63-66.

30. Foldvary CM, Takacs E \& Wojnarovits L. Effect of high-energy radiation and alkali treatment on the properties of cellulose. Radiatin Physics and Chemistry. 2013; 67: 505-508.

31. Nasirizadeh N, Dehghanizadeh H, Yazdanshenas ME, Moghadam MR \& Karimi A. Optimization of wool dyeing with rutin as natural dye by central composite design method. Industrial Crops and Products. 2012; 40: 361-366.

32. Bandaranayake WM. (2002). Bioactivities, bioactive compounds and chemical constituents of mangrove plants. Wetlands Ecology and Managemenyt. 2002; 10: 421-452.

33. Meksi N, Haddar W, Hammami S \& Mhenni FM. Olive mill wastewater, A potential source of natural dyes for textile dyeing. Industrial Crops and Products. 2012; 40: 103- 109.

34. Javed MT, Hussaan M, Iqbal N, Adeel S, Azeem M \& Raza A. Microwave assisted valorizations of milkweed (Calotropis procera L.) leaves as an ecofriendly source of natural colorant for textile. Environmental Sciences and Pollution Research. 2017; 24: 5089-5094. 